\title{
2 WE MUST HELP OURSELVES
}

\section{Peter Ninnes}

The Leitana Nehan story begins with three women giving birth on the same day in 1990. These were personal and family crises in the midst of a humanitarian crisis. Helen Hakena, in a speech delivered at the International Women's Day celebrations in Australia in 2003, recalled

[i]n 1990, when PNG withdrew all services from Bougainville and imposed a total blockade on the island, I was seven months pregnant with my fourth child. Late one afternoon the Bougainville Revolutionary Army chased my husband to our home (in Hahela) after he refused to give them our car. Previously, BRA elements had taken five of our company's vehicles. Kris, my husband, managed to run and hide in the bushes but he had no time to tell me and my three children. We were having dinner in the house and were very surprised to see eleven gunmen come into our home demanding to see my husband. I told them that we didn't know where Kris was, but still they refused to listen, continuing to point guns at me and the children and calling us names, even threatening to shoot us if Kris didn't show up.

The village people found out what was happening and came to our assistance. The gunmen left but the next day they returned in force, beating anyone in their path and destroying homes. Our entire village fled and hid in caves in the cliffs. It was then that I felt labour pains and saw blood. I was also sick with malaria, but we were too scared to leave our hiding place.

My husband sent a runner to get the local doctor as the hospital was closed because of the conflict, and there were no nurses. The doctor persuaded my husband to take me to town. The doctor gave me antimalarial drugs and then, as the hospital was locked, he took me to an old abandoned South Pacific Bank building. It was here, on a bare floor with no light or electricity, and no incubator or oxygen, that I gave birth prematurely to my son Max.

Two other women gave birth in the bank that day. Rena suffered massive blood loss and died ten days after the birth of her son. Maria 
died from complications caused by a previous caesarean section, although her son survived. After watching these women suffer such tragic deaths, Helen was determined to do all she could to end the violence and deprivation of the war. Ten days after Max was born, however, the entire village where they were staying (Ieta, Helen's husband's village) was burnt to the ground. The family again had to flee to Helen's mother's home, Gogohe, in central Buka. The other residents of Ieta were dispersed all over Buka Island. They were brought to Kubu, just north of Buka town, in November 1990 and placed in a care centre by the PNGDF, following the return of the defence forces to Buka in September of that year.

Even at this early stage of the conflict, many women were becoming victims of sexual assault by combatants. Kris and Helen and their children were the first family to move back into Buka town after the PNGDF returned. As a result, they often hosted other families from various parts of Bougainville who needed somewhere to stay in town. One of the early tasks that Helen undertook to help local women was to advise them to get home before dark after coming to the market. This was to avoid becoming victims of abuse by members of the PNGDF, who would take women away in boats to nearby small islands and rape them. Helen and Kris witnessed two incidents in which women had jumped into the sea to escape. The work took on a more coordinated form in 1992 when Helen's schoolfriend from St Mary's Girls' School in Asitavi, central Bougainville, Agnes Titus, came to Buka from her home on Nissan Island. Agnes stayed at Helen's home, and they discussed the impact of the war on Bougainville women and children. They decided to use the Catholic Women's Association network to find ways to help women and children. This network remained strong despite the war. When Helen was elected Coordinator of the Catholic Women's Association (CWA) in 1992, it had groups operating in 32 parishes throughout Bougainville. The impact of these CWA groups was seen as early as 1990, when the Gogohe CWA, led by Anastasia La Pointe, attempted to organise a peace march to Buka town. The plan was for over 1,000 women to march and air their views about the lack of services caused by the total blockade of the island. The BRA, however, announced 
that the march would not be possible, and the march organisers were taken to unknown locations where they were verbally abused and threatened. The peace march never took place.

Two other school friends from St Mary's, Alina Longa and Brenda Tohiana, later joined Agnes and Helen. Between the four of them, they had chiefly and denominational connections in most parts of Buka and Nissan. Helen was from Gogoghe on the east central coast of Buka, while her husband Kris was from Ieta in the southeast corner. Agnes was from Nissan; Brenda's home village was Hanahan in the north of Buka, and Alina came from Lemanmanu in the northwest corner of Buka. While each of these founding members of Leitana Nehan had common experiences and connections through the chiefly system, St Mary's school and the CWA, they also brought different life experiences that contributed to Leitana Nehan's initial work. Each had been either President or a member of the student executive at St Mary's. Helen had been a primary school teacher for 15 years before the crisis, while Alina had been a high school home economics teacher in schools throughout Bougainville, including Hutjena High School on Buka, and Buin and Arawa High Schools on Bougainville island itself. Brenda brought experience as an accountant, while Agnes had worked for 16 years as a community development officer for Bougainville Copper Limited, where she gained many insights from her work with women and awareness of the social issues arising from the mine's operations. Agnes also brought to the group some finetuned thinking about, and long-standing involvement with, women's issues, having been the founding President of the North Solomons Provincial Women's Council in 1978 and a founder of the North Solomons Women's Investment Corporation in 1980. Along with Elizabeth Cox, Agnes attended the World Women's Forum in Nairobi in 1985, four years before the crisis began.

On the beginning of her own work with women and children during the crisis, Agnes recalls that her international experiences made her realise, 'we can't live with our suffering. We have to help ourselves'. Prior to teaming up with Helen, Agnes had put into practice on Nissan an idea that she had picked up in Nairobi-that, during times of war, maximum effort should be made to maintain services 
for children. The school in Nissan had been closed as a result of the crisis, so Agnes called a meeting of Nissan women, who, drawing on Agnes's experiences with similar groups in Brisbane, together formed a 'ladies' auxiliary' group which ran the Tungol school on Nissan. Eventually, the ladies' auxiliary managed to recruit two women teachers who continued to operate the school.

Helen also attempted to restore primary education in Lose village, in the Gogohe area. Realising that the many children in the area were growing up without any education, she started a school underneath her house in 1989, which soon attracted children from the nearby villages of Hanpan and Suni. Parents contributed K5 each, and this was used to buy chalk and pieces of masonite to write on. About 30 children attended the school, which Helen taught in from $7 \mathrm{am}$ to 10am daily for about a year. In 1990, however, the security situation in Gogohe deteriorated. Soon after the PNGDF arrived in Buka, Helen closed the school and the family moved to Buka town.

One of Helen's early tasks as the newly elected coordinator of the CWA was to organise a meeting of the Buka island CWA groups at Hahela on 8 November 1992. It was as a result of this meeting that Helen and Agnes decided to form the Leitana Nehan Women's Development Agency, with the goal of promoting peace and creating a world safe for women and children. The name was derived from the pre-colonial names for Buka and Nissan respectively, and reflected the early, intended geographical focus of the organisation. This focus was dictated by two factors. First, the security situation at the time restricted movement on the island of Bougainville itself. Second, using the word 'Bougainville' in the name would have been politically difficult, given the divisions that existed in the islands at the time. The organisation did not have a formal motto at first, but later they decided on 'women weaving Bougainville together'. Key supporters of the organisation during its early years, who acted as resource persons, were three of the founders' spouses-Julius Longa, Kris Hakena and Michael Titus-George Lesi, who was the Administrator (that is, head) of the Bougainville provincial civil service, and Father Hendry Saris. ${ }^{1}$ The organisation set up office underneath Kris and Helen's home in Buka town, with basic facilities such as a phone/fax 
and suitable storage space. The latter was important because Leitana Nehan's first major task was to provide humanitarian relief to families in the care centres in Buka. In particular, Leitana Nehan supplied second-hand clothing to these families, which had few or no outside sources of income and were often displaced from their own land and were thus unable even to undertake subsistence farming activities. Through Father Saris, Leitana Nehan was able to link up with Karl Hesse, Archbishop of Rabaul (East New Britain Province), who began sending the organisation bundles of second-hand clothes to be distributed to families in care centres in Hanahan, Hahalis, Gogohe, Kubu, Hahela, Saposa Island and Hon Island. At various times, Leitana Nehan also organised shipments of other materials such as spades, bush knives, mattresses, stretchers and kitchen implements to needy families ${ }^{2}$ in Buka and in Paruparu and Morotona on mainland Bougainville. The Red Cross later took over this work.

When the organisation was founded, it was not formally registered as an NGO. The Leitana Nehan founders played a variety of roles in the Provincial Council of Women (PCW) in the early 1990s, and Agnes Titus was elected president of that group in 1994. There were limitations, however, to the activities that could be undertaken as executive members of the PCW, and these caused the founders to establish Leitana Nehan more formally (Chapter 3).

Another early activity of Leitana Nehan involved sending medicine to care centres. Agnes had organised a shipment of medicine to Nissan through Steve Cooper from the Save the Children Fund office in Goroka in the Papua New Guinea highlands. When Helen heard that Steve was coming to Bougainville, she contacted him and arranged for him to send consignments of medicine to Bougainville. The first batch was shipped in metal patrol boxes across the Buka passage to Kokopau on mainland Bougainville, but the shipment was intercepted by the PNGDF and destroyed. When other batches arrived in Buka, it was realised that a more secure method was required to ensure the safe passage of these much-needed supplies. A system was set up in which mothers travelling to the mainland would return with medicine concealed in their baskets, hidden beneath soiled nappies, feminine hygiene products or underwear. Male soldiers from 
either side of the conflict were very reluctant to poke around in baskets containing such items. They believed that touching such items would lead to premature aging or result in bad luck. In this way, the medicine and clothes were distributed via Kokopau, which is just across the passage from Buka town, and also via Saposa Island off the northwest coast of Bougainville, to various parts of the interior of the mainland.

The relief work in care centres continued through 1993, but in that year Leitana Nehan also began to make contact with outside groups and individuals. Such contact played a major role in Leitana Nehan's development from a relatively ad hoc humanitarian relief organisation to a fully-fledged NGO focusing on rehabilitation, reconciliation and development efforts. One very important connection made that year was with Rae Smart, who suggested that Leitana Nehan become an NGO. Rae had worked at the Arawa Technical College until 1989, and knew Agnes through the North Solomons Women's Investment Corporation. In 1993, Leitana Nehan tried to get permission for Rae and a freelance journalist, Sharon Laura, to visit Bougainville, but they were not granted clearance. No outsiders were being allowed into Buka at that time, and even residents of Buka were issued with a red passport when they gained permission to leave the province. Even today, people remark half-seriously that it was when those red passports were issued that Bougainville gained its independence.

In 1994, however, Rae and Sharon did make it to Bougainville. The restriction on outside visitors was temporarily lifted, and they were granted clearance by the then Administrator, the late George Lesi, who later became Assistant Executive Director of Leitana Nehan. At this time, the PNGDF had lifted the blockade of the mainland for a month, which meant that people no longer needed permission from the PNGDF to have large gatherings on Buka. Helen, as coordinator of the CWA, took the opportunity to organise a 'Bougainville Reunion' at Hahela of CWA women from all 32 Bougainville parishes, using funding organised through Julie Eagles from the Australian NGO Community Aid Abroad. ${ }^{3}$ Approximately 2000 women came by foot and by boat to the reunion, which was held on 15 August 1994, where they were welcomed and sang songs 
about their suffering. They were encouraged to pray, talk and negotiate with the parties involved in the conflict to stop the fighting. The reunion was a sign of unity, confidence, courage and determination to move the peace process forward. Sharon and Rae, whose trip was financed by the International Women's Development Agency, documented the experiences of the Bougainville women during the crisis, and made a video of the meeting. They smuggled the video cassettes out of Bougainville taped to their legs, while some other film departed on the same flight, hidden under babies' nappies.

During 1994, Leitana Nehan also started facilitating a range of courses, often in conjunction with the Catholic Women's Association network and Catholic Family Life, with which Alina was involved. These included courses on family life and counselling. The organisation began collecting the names of widows and single mothers created by the war and documenting the atrocities they had faced, including the names and affiliation of perpetrators if these were known. Over 2,000 names were recorded, although a large number of the records were lost when intruders broke into the Leitana Nehan office and stole them. The perpetrators of this theft were never discovered, although military personnel from both sides who had abused women may have felt threatened by the record of these human rights abuses. Not all of the records were stolen, and the remainder were videotaped for safe keeping by Father Malak from the Catholic media organisation in Port Moresby.

Leitana Nehan also assisted 105 women to attend the Catholic Women's Federation conference in Port Moresby from 1-9 September 1994. Helen, in her role as Coordinator of the Bougainville Diocese Catholic Women's Association, managed to arrange transport through an old school friend, Leona Kilo, who was working at the time for the PNG national carrier, Air Niugini.

Flavia Arnold and Elizabeth Andoga, specialists in small incomegenerating projects and book-keeping from the Business Enterprise Support Team (BEST) in Madang, also visited Buka in 1994. They came to train CWA women, but their training did not have much impact, because the women were still in the midst of the crisis and were not in a position to commence such projects safely. 
The Arawa peace talks were held on 10-14 October 1994. Agnes gave the first plenary speech in her role as President of the PCW and declared 'we have not come here to negotiate for peace; we have come to demand it' (Weeks 1994:25). She went on to address her remarks to women on both sides of the conflict.

I want to talk to my sisters Mrs Ona, Mrs Kabui and Mrs Kauona [the wives of the secessionist leaders] and all sisters and mothers. What you feel, we have felt. The pain of mothers giving birth in the bush—we have felt it. I am a mother and I have children that I love. You are the same. My heart cried when soldiers on both sides were killed. We are mothers; we carried these children. Why must this go on? Give peace a chance. Come out of the bush. Please hear us. All mothers, please hear us (Weeks 1994:25).

During the talks, Agnes also spoke to Joe Kabui by two-way radio and pleaded with him to join the talks under the security of the South Pacific Peace Keeping Force, but he refused (Weeks 1994).

Helen was not able to attend the Arawa peace talks, because she had received two threatening letters as a result of her strong advocacy for peace. Her children had also been threatened. She did, however, arrange for Catholic mothers and children to attend, and they slept under the Hakenas' house in Buka town on their way to Arawa.

The various workshops organised under the auspices of Leitana Nehan became more widespread in 1995. Using K5,000 in funding from the International Women's Development Agency (IWDA), Leitana Nehan was able to organise workshops to raise awareness of alcohol abuse and violence against women, using teams of volunteers that included Francis Botsia, Elizabeth Behis, Yvonne Baito, Leonard Mokela, Bianca Hakena, Audrey Katia, Alina Longa, Helen Hakena and two seminarians, Abel Willie and Chris Rere. These volunteers were paid an allowance of K5 per workshop to cover their expenses (about one US dollar on current exchange rates).

As well as running local workshops, the founders of Leitana Nehan were involved in wider issues concerning women and peace. Alina travelled to Canberra to attend the Bougainville peace talks held on 22 June 1995, and she also attended the National Catholic Women's Conference in Kundiawa, in the PNG highlands. It was in this year, too, that the Fourth Global Conference on Women was held in 
Beijing. Agnes had attended the NGO forum associated with the earlier conference in Nairobi, and in 1995 she attended the preBeijing preparatory workshop for the South Pacific region, held in Wewak, on the north coast of Papua New Guinea. In September 1995, Helen and Agnes attended the NGO forum associated with the Beijing conference. In many senses this forum represents a key point in the development and direction of Leitana Nehan. Collectively, the founders were increasingly being exposed to a range of ideas and issues concerning women, human rights, peace and humanitarian relief through their own experiences of the conflict, through attending conferences, by being involved with the PCW and the CWA, as a result of support from Community Aid Abroad (CAA) and IWDA, and through early activities such as the Bougainville reunion and the initial awareness workshops. The Beijing forum, however, turned out to be an important catalyst for change in the organisation's identity, focus and means of operation.

IWDA organised funding for Agnes and Helen to go to Beijing. In Beijing, Helen and Agnes felt that the PNG women shunned them at first, but when they heard what it was like in Bougainville, their attitude softened. Even the Bougainville women who had been living behind the blockade and had travelled to Beijing via the Solomon Islands also initially kept their distance. However, Helen and Agnes encouraged all the Bougainville and PNG women to attend each other's sessions and as a result they discovered that they all had a common desire-peace.

For Helen, Beijing was particularly valuable for a number of reasons. She learned from other women in conflict situations about the work they did and how strong they were. She was exposed to wider issues of peace and conflict in other countries, and extended her networks, especially with respect to training, lobbying and solidarity. Helen observed that there were many different groups attending the conference in Beijing who were just doing work for and with women (not men or children). However, Helen and Agnes believed that in Bougainville, families do things together-husbands, wives, uncles, aunties, children; every family member is included. They really wanted to include women, men and children in their work, and they decided 
that an organisation focusing on, and working only with, women would not be accepted by communities in Bougainville. This is one of the major reasons why Leitana Nehan works with both men and women, has women and men in its executive positions, and women and men in its volunteer teams. The Leitana Nehan founders also recognised that both men and women needed to be part of the efforts to attain and maintain peace in Bougainville. Helen remarked in a recent speech

$[\mathrm{w}] \mathrm{e}$ recognise the strong connection between violence against women and the militarisation of Bougainville society. Because of this, Leitana Nehan is working not only with women but also with men, youth and entire communities towards reconciliation and freedom from violence. Building relationships between young people from different communities within Bougainville has been one of our approaches in healing the rifts created by war. We work with ex-combatants and encourage men to be involved in our work to assist their recovery, to 'balance the teams' sharing of experiences' and to involve men in peace-building. 'Hard core' guerrillas are now working with us and talking to communities about the impact of violence on women. They offer powerful role models to other young men in the community. Our anti-violence workshops help boys and young men to understand that the guns and violence of their childhood are not a necessary part of their futures (Hakena 2003:n.p.).

Prior to the Beijing forum, Agnes and Helen did not know much about women's rights and women's issues except what Agnes had picked up on her visit to Nairobi or what they had gleaned from people like Rae Smart. The Beijing forum raised their awareness of concepts and issues concerning human rights. Before Beijing, they had focused on improving family life, living well together as a family and a community, and re-establishing women's traditional leadership role in the family as custodian of the land and resolver of conflicts. The reestablishment of women's roles was at the time (and still is) an important task for Leitana Nehan, because colonialism and the war had severely eroded women's traditional leadership, conflict resolution and custodial roles. However, the women's rights ideas added to and strengthened their ideas about how communities should operate.

When Helen and Agnes returned from Beijing, they discussed the concepts of women's and human rights with people in the parishes on Buka, who agreed that women's rights were compatible with what 
they needed. As a result, women realised they needed to speak out about their rights because many men were traumatised by the conflict or too intimidated or scared to speak out. For example, two of Helen's uncles were murdered in front of their children because they had spoken out about BRA-instigated killings and disappearances at Hanahan.

Agnes and Helen were driven by concern about the bloodshed and abuses that were occurring during the Bougainville crisis, and their desire for peace and an end to the violence. This motivated them, in the early days of Leitana Nehan, to undertake humanitarian relief for the families in the care centres, and then to expand their work to include organising meetings and awareness workshops using available funds. During these early years, the founders, especially Helen and Agnes, expanded their understanding of women's issues, and began to develop a network of supporters, mentors and allies within Bougainville, Papua New Guinea and in the wider world. The Beijing forum was a pivotal event, and in the next chapter I examine in detail the impact on Leitana Nehan of that event and its expanding work at local, provincial, national and global levels.

\section{NOTES}

1 A list of Leitana Nehan staff and volunteers for the period 1992-99 is found in Appendix 1.

2 Garasu (2002) identifies two other organisations involved in this kind of relief work at various times: the Catholic Women's Association and the Bougainville Community Integrated Development Agency (BOCIDA).

3 Garasu (2002) says that the Bougainville Reunion was organised by 'Catholic women' but does not specifically mention Leitana Nehan. 